Исследуемый объект чувствителен к низким значениям солености воды, как это было указано выше: уже руководствуясь этим фактом, предполагается, что этим можно объяснить более медленный темп роста моллюсков из Онежкского залива.

Несмотря на то, что температура и соленость морской воды являются фундаментальными факторами окружающей среды, которые воздействуют на гидробионтов, нельзя не учитывать, что в природе всегда работает комплекс факторов. Это волновая гидродинамика, влияние антропогенного компонента среды. Поэтому, исследование будет продолжено.

Данная работа существенно дополняет материалы для изучения биологии и экологии Littorina littorea L.

$$
* * *
$$

1. Акимова Е. В., Шкляревич Г. А. Скорость роста брюхоногого моллюска Littorina littorea L. в Кандалакшском заливе Белого моря // Принципы экологии. 2016. Т. 5. № 1. С. 63-74.

2. Алимов А. Ф., Макарова Г. Е., Максимович Н. В. Методы изучения двустворчатых моллюсков. Л.: Изд-во Зоологического ин-та АН СССР, 1990. 196 с.

3. Белое море. Биологические ресурсы и проблемы их рационального использования / Под. ред. О. А. Скарлато. Ч. 1. СПб.: Изд-во Зоологического ин-та РАН. 1995. 250 с.

4. Бергер В. Я. Дыхание некоторых литоральных моллюсков в процессе акклиматизации к изменениям солености воды // Экология. № 5. Свердловск: Наука, 1970. С. 68-72.

5. Бескупская Т. И. Питание некоторых массовых литоральных беспозвоночных Белого моря // Труды Кандалакшского заповедника. Труды биологической станции МГУ. 1963. Вып. 4. Т. 2. С. 135-169.

6. Бианки В.В., Семашко В. Ю., Черенков А.Е. Морские птицы Онежского залива Белого моря (современное состояние и изменения численности) // Изучение динамики популяций мигрирующих птиц и тенденций их изменения на Северо-Западе России. 2006. Вып. 5. С. 102 - 121.

7. Болотов И. Н. Пути формирования фауны Соловецкого архипелага (Белое море, Северо-Запад России) // Зоологический журнал. Т. 93. № 1. С. 129 - 144.

8. Зотин А. А., Озернюк Н. Д. Сравнительное изучение энергетического обмена у литоральных моллюсков Белого моря // Проблемы изучения, рационального использования и охраны природных ресурсов Белого моря. Материалы Х международной конференции. 2007. С. 133-136.

9. Зубов Н. Н. Океанологические таблицы. Л.: Гидрометеорологическое изд-во, 1957. 406 с.

10. Мина М. В., Клевезаль Г. А. Рост животных: анализ на уровне организма. М.: Наука, 1976. 291 с.

11. Моллюски Белого моря / Под ред. О. А. Скарлато. Л.: Наука, 1987. 328 с.

12. Рубинчик M. А. К биологии размножения Littorina littorea L. Белого моря// Биология Белого моря. T. 1. М.: Изд-во МГУ, 1962. С. 215-230.

13. Седловская С. М. Рост и продуктивность беспозвоночных животных: Метод. рекомендации. Витебск: УО «ВГУ им. П. М. Машерова», 2012. 48 с.

\title{
Шаманова Ф.X. \\ Поведение растений альпийских ковров Тебердинского государственного биосферного заповедника на удаление доминантов
}

Северо-Кавказская государственная гуманитарно-технологическая академия (Россия, КЧР, с. Светлое)

doi:10.18411/spc-22-10-2017-07

idsp: 000001:spc-22-10-2017-07

Альпийские ковры на территории Тебердинского государственного биосферного заповедника больших пространств не занимают, а встречаются лишь небольшими участками, где абсолютным доминантом может выступать Sibbaldia procumbens, содоминантами - Taraxacum stevenii, Nardus stricta, Minuartia aizoides, Gnaphalium supinum.

Как повлияет на структуру сообщества выпадение одного из доминирующих видов? Ответ на этот вопрос позволит определить, какие из видов наиболее близки по своим экологическим свойствам, а какие - менее, какие виды сильнее конкурируют друг с другом за почвенные ресурсы.

Эксперимент по изучению конкурентных взаимоотношений между видами на альпийских коврах был заложен в 1998 году, он продолжается и по настоящее время. Для этого было произведено удаление основных доминантов Sibbaldia procumbens и 
Taraxacum stevenii. Удаление осуществляли методом истощения соответствующих растений, то есть многократным срезанием их надземных побегов ножницами, что не вызывало нарушений почвенного покрова и повреждений надземных побегов других сосудистых растений.

Опыты заложены на пробных площадках $1 \mathrm{~m}$ х $0,5 \mathrm{M}$ (повторность четырёхкратная). Оценку результатов проводили на трёх площадках $25 x 25 \mathrm{~cm}$, расположенных в центре каждой площадки 1м х 0,5 м в четырёх вариантах:

1. контроль;

2. удаление Taraxacum stevenii;

3. удаление Sibbaldia procumbens;

4. удаление Sibbaldia procumbens и Taraxacum stevenii.

Как показатель изменения структуры фитоценоза используется численность особей (побегов) сосудистых растений (в - вегетативные, г - генеративные, ю ювенильные) до удаления доминантов. Каждый год подсчитывали число вегетативных, генеративных и ювенильных особей, в случае злаков и осок, учитывали только численность генеративных и вегетативных побегов.

Для статистической обработки результатов эксперимент был использован дисперсионный анализ. По его результатам из 24 видов на удаление доминантов значимую реакцию проявляют: Taraxacum stevenii, Corydalis conorhiza, Carum meifolium, Minuartia aizoides, Gnaphalium supinum, Hyalopoa pontica, Catabrosella variegata, Agrostis vinealis, Anthoxanthum odoratum, Festuca ovina, Phleum alpinum.

На эксперименте при удалении Taraxacum stevenii увеличивают численность побегов следующие виды: Corydalis conorhiza, Hyalopoa pontica, Catabrosella variegata, Festuca ovina, а значимое снижение численности побегов наблюдается у Phleum alpinum.

На эксперименте при удалении Sibbaldia procumbens показали значимое увеличение численности побегов следующие виды: Taraxacum stevenii, Carum meifolium, Gnaphalium supinum, Catabrosella variegata, Anthoxanthum odoratum, Phleum alpinum, а значимое уменьшение численности - Agrostis vinealis.

На эксперименте при совместном удалении обеих доминантов Sibbaldia procumbens+Taraxacum stevenii значительное увеличение наблюдается - у Corudalis conorhiza, Carum meifolium, Minuartia aizoides, Gnaphalium supinum, Catabrosella variegata, Phleum alpinum, а уменьшение только у Agrostis vinealis.

Для видов, у которых происходит значимое увеличение численности при удалении того или иного доминанта, фактор конкуренции оказывается более значимым, чем неблагоприятные условия среды.

\section{Шаманова Ф.X. \\ Экспериментальный подсев Carum caucasicum на нарушенные участки альпийских ковров}

Северо-Кавказская государственная гуманитарно-технологическая академия (Россия, КЧР, с. Светлое)

doi:10.18411/spc-22-10-2017-08

idsp: 000001:spc-22-10-2017-08

Carum caucasicum (Bieb.) Boiss. - травянистый поликарпик, полурозеточный, стержневой, вегетативно неподвижный геофит. Энтомофил. В ТГБЗ встречается в альпийском и субнивальном поясах, доходя до 3750м, но особенно характерен для альпийского пояса, где произрастает на пустошах и коврах. Этот вид является субэндемом Кавказа. Поселяется на средних стадиях сукцессии, приводящих к образованию ковра. Имеет везикулярно-арбускулярную микоризу.

Эксперимент проводили на нижних участках альпийских ковров, которые располагались на абсолютной высоте 2800м на горе Малая Хатипара в ТГБЗ. 